\title{
PEMANFAATAN BAKTERI PROBIOTIK INDIGENUS DALAM PEMBUATAN KEJU LUNAK
}

\author{
[Utilization of Indigenous Probiotic Bacteria in the Production of Soft Cheese]
}

\author{
Fifi Afiati1)*, Yopi1) dan Rarah R.A. Maheswari²) \\ 1) Pusat Penelitian Bioteknologi LIPI, JI. Raya Bogor Km 46, Cibinong, Bogor \\ 2) Departemen IImu dan Teknologi Peternakan, Fakultas Peternakan, Institut Pertanian Bogor, Bogor
}

Diterima 12 April 2013 / Disetujui 15 Februari 2014

\begin{abstract}
Probiotic soft cheese containing lactic acid bacteria is one of functional food products. Three lactic acid bacteria namely Lactococcus lactis DSB 42 (LL-DSB42), Lactobacillus acidophilus RRM-01 (LA-RRM01) and Bifidobacterium longum RRM-01 (BL-RRM01) were used in the production of probiotic soft cheeses. Single culture (BL, $L A$, and $L L)$ and mixed culture (BL-LA, BL-LL, LA-LL and BL-LA-LL) were used to produce diversified functional products. The preparation of probiotic soft cheese consists of pasteurization, addition of lactic acid bacterial culture (5\%, $v / v)$, addition of rennet, cutting the curd, scalding, draining and packaging. Soft cheese characteristics were analyzed physically (yield), chemically (pH, water content, crude protein, crude fat and ash) and microbiologically (lactic acid bacteria). The results showed that addition of lactic acid bacteria cultures significantly decreased the $\mathrm{pH}$ value ( $\mathrm{pH} 5.10$ to 5.79). The yield of probiotic soft cheese produced was in the range of $17.86-22.51 \%$ with water content of more than $55 \%$. The fat and carbohydrate content of both cheeses of single and mixed cultures were significantly different $(p<0.05)$ (fat content $5.1-7.4 \%$ for single culture and $4.0-9.3 \%$ for mix culture; carbohydrate content $11.6-17.7 \%$ for single culture and $4.6-12-2 \%$ for mix culture). The combination of all three starter cultures did not result in inhibition to each other, thus these combination were able to achieve the maximum number of $9.0 \log _{10} \mathrm{CFU} \mathrm{g}^{-1}$ on a single culture soft cheese and $9.8 \log _{10} \mathrm{CFU} \mathrm{g}^{-1}$ in mixed cultures soft cheese. In conclusion, soft cheeses with single culture (BL, LA, and $L L)$ and mixed culture (BL-LA, BL-LL, LA-LL and BL-LA-LL) had excellent potential properties to be developed as probiotic foods.
\end{abstract}

Keywords: B. longum, lactic acid bacteria, L. acidophilus, L. lactis, soft cheese

\begin{abstract}
ABSTRAK
Keju probiotik menggunakan bakteri asam laktat merupakan salah satu produk pangan fungsional. Bakteri asam laktat (BAL) yang digunakan dalam pembuatan keju lunak adalah Lactococcus lactis DSB 42 (LL-DSB42), Lactobacillus acidophilus RRM-01 (LA-RRM01) dan Bifidobacterium longum RRM-01 (BL-RRM01), baik secara tunggal (BL, LA, and LL) atau campuran (BL-LA, BL-LL, LA-LL dan BL-LA-LL) yang bertujuan meningkatkan diversifikasi produk menjadi pangan fungsional. Penelitian dimulai dari proses pasteurisasi, penambahan BAL (5\%, v/v), penambahan rennet, pemotongan curd, scalding, penyaringan dan pengemasan. Keju lunak dianalisis secara fisik (rendemen), kimia ( $\mathrm{pH}$, kadar air, lemak kasar, abu dan karbohidrat by difference). Penambahan BAL menyebabkan penurunan pH (pH 5.10 sampai 5.79). Rendemen yang dihasilkan betrkisar $17.86-22.51 \%$ dengan kadar air lebih dari 55\%. Kandungan lemak dan karbohidrat berbeda nyata $(p<0.05)$ baik yang ditambah BAL secara tunggal atau campuran (kadar lemak 5.1-7.4\% pada kultur tunggal dan 4.0-9.3\% pada kultur campuran; kandungan karbohidrat 11.6$17.7 \%$ pada kultur tunggal dan 4.6-12-2\% pada kultur campuran). Kombinasi ketiga kultur starter tidak menyebabkan penghambatan pada kultur lainnya, sehingga mampu tumbuh maksimum $9.0 \log _{10} \mathrm{CFU} / \mathrm{g}$ pada kultur tunggal dan $9.8 \log { }_{10} \mathrm{CFU} / \mathrm{g}$ pada kultur campuran. Disimpulkan bahwa keju lunak dengan kultur tunggal atau campuran berpotensi sebagai makanan probiotik.
\end{abstract}

Kata kunci: bakteri asam laktat, B. longum, keju lunak, L. acidophilus, L. lactis

\section{PENDAHULUAN}

Beragamnya jenis pangan di Indonesia memicu beberapa industri untuk mengembangkan produk berbasis susu. Keju merupakan produk susu yang memiliki karakteristik fisik dan kimia spesifik dibandingkan produk susu lainnya serta berpotensi sebagai probiotik (Karimi et al. 2011). Pembuatan keju merupakan proses dehidrasi susu dan dipengaruhi oleh faktor lain seperti kultur, pengasaman, pengasinan, kemasan dan pendinginan (Everett dan Auty, 2008).

*Penulis Korespondensi:

E-mail: fifi.afiati@lipi.go.id; afiati_btk@yahoo.com
Bakteri probiotik berfungsi efektif jika viabilitasnya dapat dipertahankan sampai usus halus dan usus besar. Bakteri probiotik bertanggung jawab melindungi tubuh manusia dari infeksi, terutama di sepanjang permukaan mukosa saluran pencernaan (Sanders, 2003). Bakteri asam laktat seperti $L$. acidophilus, Bifidobacterium spp dan $L$. casei sering digunakan dalam pembuatan produk-produk yang terbuat dari susu dan juga sebagai bagian dari mikroflora gastrointestinal (Shah, 2007).

Bakteri asam laktat tergolong mikroorganisme Generally Recognized as Safe (GRAS), aman jika ditambahkan ke dalam bahan pangan dan bersifat non toksik, sehingga dapat dimanfaatkan dalam pembuatan produk pangan fermentasi (Kusmiati dan Malik, 2002). Strain bakteri yang tergolong dalam 
bakteri probiotik adalah dari genus Laactobacillus dan Bifidobacterium (Madureira et al. 2005) saat ini bakteri probiotik banyak digunakan dalam yoghurt, es krim dan makanan penutup (Homayouni et al. 2008).

Lactobacillus acidophilus merupakan bakteri yang tahan terhadap $\mathrm{pH}$ rendah dan cocok untuk digunakan dalam pembuatan produk olahan susu dengan keasaman tinggi (Vedamuthu, 2006). Dilaporkan juga $L$. lactis merupakan bakteri asam laktat yang dimanfaatkan dalam dunia industri untuk memproduksi produk susu fermentasi khususnya keju (Odamaki et al. 2011). Disisi lain bifidobacteria dilaporkan mampu memanfaatkan laktulosa dan oligosakarida yang merupakan karbohidrat komplek dan dikenal dengan istilah 'faktor-faktor bifidus'. Interaksi positif antara beberapa strain bakteri asam laktat tersebut diatas telah banyak digunakan seperti $L$. acidophilus dan Bifidobacterium spp. (Tamime dan Robinson, 2000). L. helveticus R0052, B. longum R0175 dan B. lactis BB-12 merupakan strain yang dapat memberikan efek kesehatan (Rautava et al. 2009; Jandu et al. 2009; Wagar et al. 2009). Mikroorganisma genus laktokokus dianggap aman sehingga banyak digunakan dalam produk olahan susu, baik dalam skala kecil atau besar (Casalta dan Montel, 2008).

Penelitian menggunakan bakteri asam laktat Lactobacillus acidophilus RRM-01 (LA-RRM01), Bifidobacterium longum RRM-01 (BL-RRM01) dan Lactococcus lactis DSB 42 (LLDSB42), karena menurut Maheswari et al. (2008) bakteri tersebut berpotensi sebagai probiotik yang mampu menghambat pertumbuhan bakteri patogen, khususnya $E$. coli. Ketiga bakteri yang digunakan merupakan bakteri asam laktat yang diisolasi dari produk lokal, yaitu dadih dari Sumatera Barat sehingga diharapkan mampu meningkatkan potensi plasma nutfah lokal. Tujuan pemanfaatan bakteri LA-RRM01, BL-RRM01 dan LLDSB42 pada keju lunak adalah untuk meningkatkan diversifikasi produk menjadi pangan fungsional melalui proses fermentasi bakteri asam laktat secara tunggal atau campuran dalam pembuatan keju lunak terhadap karakteristik fisik, kimia dan mikrobiologi.

\section{BAHAN DAN METODE}

\section{Bahan}

Susu segar diperoleh dari sapi Friesian Holland (FH) yang dipelihara di Pusat Penelitian Bioteknologi LIPI Cibinong. Bahan lain yang digunakan adalah susu skim dari supermarket lokal, dan rennet, kultur Lactobacillus acidophilus RRM-01 (LARRM01; LA), Bifidobacterium longum RRM-01 (BL-RRM01; BL) serta Lactococcus lactis DSB 42 (LL-DSB42; LL) dari Laboratorium Hasil Ternak Perah, Fakultas Peternakan IPB.

\section{Analisis kualitas susu segar}

Analisis susu menggunakan pH meter (MV meter UB-7) dan milko tester (Master Pro) meliputi nilai pH, kadar lemak, protein, laktosa.

\section{Persiapan kultur bakteri}

Persiapan dimulai dengan mengaktifkan kultur BAL dalam media de Mann Rogossa Sharpe Broth (MRSB, Merck) steril

sebanyak 2-3 x 24 jam dalam 9 bagian media cair steril dan 1 bagian kultur. Perbanyakan kultur dilakukan melalui tahap pembuatan kultur induk, kultur antara dan kultur kerja, dimana 1 bagian kultur BAL ditumbuhkan dalam 9 bagian larutan skim steril.

\section{Pembuatan keju lunak}

Masing-masing kultur kerja 5\% (v/v) ditambahkan ke dalam susu yang telah dipasteurisasi dan dilakukan pengukuran $\mathrm{pH}$ hingga mencapai $\mathrm{pH}$ 6.3. Kultur kerja yang ditambahkan meliputi kultur tunggal (Lactobacillus acidophilus RRM-01/LA, Bifidobacterium longum RRM-01/BL dan Lactococcus lactis DSB 42/LL) atau kultur campuran (BL-LA 1:1, BL-LL 1:1, LA-LL 1:1 dan BL-LA-LL 1:1:1). Pada bahan tersebut kemudian ditambah rennet dan diinkubasi pada suhu $37^{\circ} \mathrm{C}$ selama 2 jam, selanjutnya dipotong-potong dan didiamkan selama 15 menit. Scalding dilakukan dengan cara pemanasan curd pada suhu $40^{\circ} \mathrm{C}$ selama 30 menit, dilanjutkan dengan penyaringan, pengemasan dan penyimpanan. Penambahan kultur kerja sampai pengemasan dapat dilihat pada Gambar 1, 2, 3, 4 dan 5.

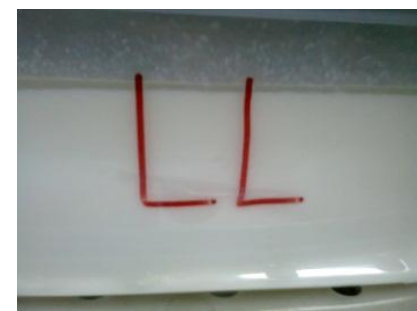

Gambar 1. Kultur kerja

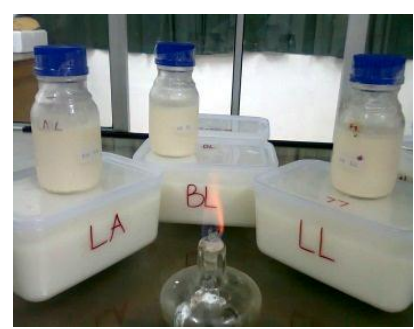

Gambar 3. Pengeluaran whey

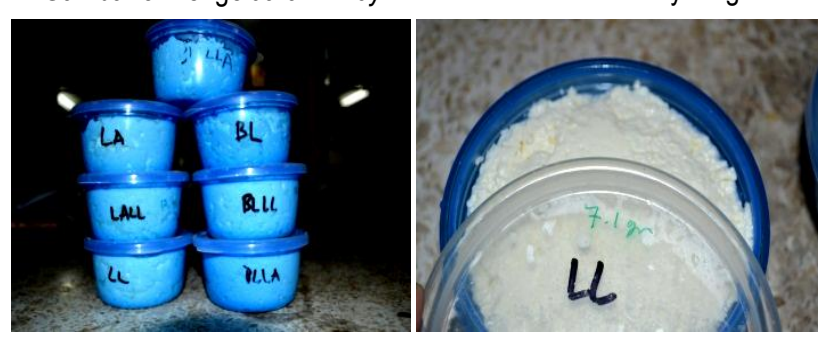

Gambar 5. Pengemasan

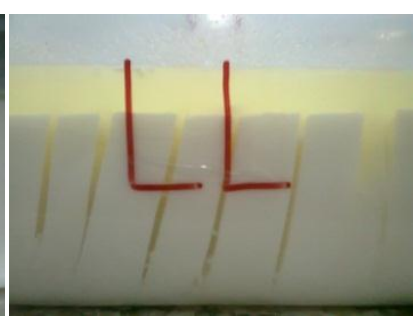

Gambar 2. Proses koagulasi

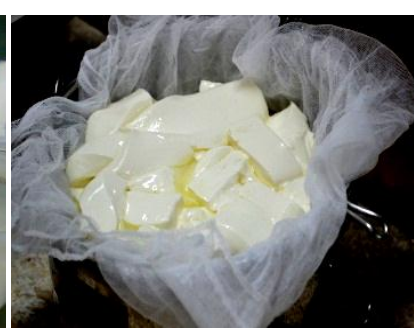

Gambar 4. Penyaringan

\section{Analisis produk}

Keju lunak yang dihasilkan dianalisis secara fisik (rendemen), kimia ( $\mathrm{pH}$, kadar air, protein kasar, abu, lemak kasar dan mikrobiologi (BAL, bakteri asam laktat). Analisis $\mathrm{pH}$ dan populasi bakteri asam laktat dilakukan terhadap keju lunak yang disimpan selama 1, 7 dan 14 hari, sedangkan analisis kadar air, protein, lemak dan abu serta karbohidrat by difference (hasil pengurangan angka 100 dengan komponen air, protein, lemak dan abu) dilakukan terhadap keju segar $(\mathrm{H} 1)$. Analisis dilakukan menurut AOAC (2005) dan BAM (2001). 


\section{Analisis data}

Rancangan penelitian pengujian analisis nilai $\mathrm{pH}$, analisis karbohidrat dan jumlah BAL menggunakan faktorial rancangan acak lengkap (faktorial RAL), analisis protein kasar, lemak kasar, kadar air dengan rancangan acak kelompok (RAK) dengan tiga kali ulangan dan dianalisis dengan sidik ragam (ANOVA). Jika terjadi perbedaan dilanjutkan dengan uji Duncan.

\section{HASIL DAN PEMBAHASAN}

\section{Kualitas susu sapi segar}

Susu merupakan bahan dasar yang diperlukan dalam pembuatan keju. Komposisi yang terkandung di dalam susu berbeda tergantung jenis ternak, bangsa ternak, status nutrisi, periode laktasi, umur, interval pemerahan dan kesehatan (McSweeney, 2007). Penentuan kualitas susu harus mengikuti standar mutu yang telah ditetapkan oleh Badan Standardisasi Nasional tentang susu sapi segar (BSN, 2011). Pengujian susu diawal proses produksi dilakukan karena susu merupakan bahan utama dalam pembuatan keju, dimana komponen susu seperti protein berperan dalam pembentukan tekstur dan flavor, sedangkan laktosa merupakan substrat terpenting dalam proses fermentasi bakteri asam laktat. Standar kandungan protein susu untuk pembuatan keju adalah $3.7-4.5 \%$. Kandungan yang standar dapat meningkatkan keseragaman, mengurangi casein dalam whey dan meningkatkan kadar protein dalam produk (McSweeney, 2007). Mutu susu sapi segar yang digunakan dalam penelitian seperti tercantum dalam Tabel 1.

Tabel 1. Mutu susu segar sapi Friesian Holland (FH) yang dipelihara di Pusat Penelitian Bioteknologi LIPI Cibinong

\begin{tabular}{ccc}
\hline Komposisi & Nilai & Nilai Standar \\
\hline Lemak (\%) & $4.9 \pm 0.7$ & $3.0^{1}$ \\
Protein (\%) & $3.8 \pm 0.2$ & $2.8^{1}$ \\
Laktosa (\%) & $4.0 \pm 0.2$ & $4.09^{2}$ \\
pH & $6.7 \pm 0.1$ & $6.3-6.8^{1}$
\end{tabular}

1SNI 3141.1:2011; 2Siddique et al. (2010)

Salah satu atribut yang dapat menentukan kualitas susu adalah kandungan laktosa dan abu (Siddique et al. 2010). Laktosa merupakan sumber energi utama bagi bakteri asam laktat yang memerlukan karbon organik sebagai sumber karbon dan energi dengan merubah menjadi asam laktat dan produk lainnya melalui dua rute metabolisme yang berbeda. Konsentrasi laktosa dan laktat berpengaruh terhadap proses pematangan keju (Riahi et al. 2007).

Mutu susu segar sapi FH memenuhi standar yang telah ditetapkan SNI 314.1:2011, sehingga susu yang dihasilkan dapat digunakan untuk produk olahan susu, khususnya pembuatan keju lunak.

\section{Rendemen keju lunak}

Rendemen dipengaruhi oleh beberapa faktor, yaitu konsentrasi rennet, temperatur dan $\mathrm{pH}$ (Walstra et al. 2006). Persentase rendemen keju lunak dapat dilihat pada Tabel 2.
Tabel 2. Rendemen keju lunak yang dihasilkan dari penambahan kultur bakteri asam laktat (BAL) secara tunggal atau campuran

\begin{tabular}{cc}
\hline Kultur Starter & Rendemen $(\%)^{\text {tn }}$ \\
\hline BL & $17.9 \pm 5.1$ \\
LA & $20.6 \pm 6.7$ \\
LL & $19.6 \pm 6.1$ \\
BL-LA & $21.6 \pm 8.4$ \\
BL-LL & $21.4 \pm 9.9$ \\
LA-LL & $21.4 \pm 6.6$ \\
BL-LA-LL & $22.5 \pm 7.3$ \\
\hline BL = Bifidobacterium longum; & LA = Lactobacillus acidophilus \\
LL = Lactococcus lactis; & tn = tidak berbeda nyata $(p>0.05)$
\end{tabular}

Kasein berfungsi membentuk jaringan parakasein untuk menghasilkan struktur keju. Secara sederhana, rendemen merupakan berat keju yang dihasilkan dari berat susu yang digunakan. Penentuan rendemen sebenarnya dihasilkan dari pengukuran semua komponen input (susu, starter dan garam) serta output (keju dan whey). Keju yang dihasilkan dipengaruhi oleh beberapa faktor, seperti spesies, bangsa, masa laktasi, nutrisi, frekuensi pemerahan dan status kesehatan ternak (McSweeney, 2007).

Secara umum, rataan rendemen yang dihasilkan dalam penelitian tidak berbeda nyata $(p>0.05)$. Hal ini menunjukkan bahwa penggunaan bakteri asam laktat LA, BL dan LL baik secara tunggal atau campuran memberikan pengaruh yang sama terhadap rendemen keju lunak, karena kultur yang ditambahkan mempunyai konsentrasi yang sama, seperti pendapat Jamilatun (2009) bahwa rendemen dipengaruhi oleh konsentrasi inokulum, suhu dan waktu fermentasi. Persentase rendemen yang dihasilkan pada penelitian ini sebesar 17.86$22.51 \%$, berkaitan erat dengan kadar air yang dikandungnya, berpengaruh juga terhadap konsistensi dan teksturnya (Farke, 2004) (Tabel 5) sehingga keju yang dihasilkan dapat diklasifikasikan sebagai keju lunak, karena menurut Heller et al. (2008) keju yang mengandung kadar air $>55 \%$ diklasifikasikan sebagai keju lunak.

McSweeney (2007) mengemukakan bahwa kadar protein dan lemak susu serta penanganan susu pada proses pembuatan keju dapat mempengaruhi perolehan rendemen. Rendemen dihasilkan dari penurunan berat keju disebabkan oleh kehilangan air akibat penguapan dan pelepasan $\mathrm{CO}_{2}$ dari proses glikolisis dan proteolisis serta dipengaruhi kelembaban relatif dan suhu lingkungan (Riahi, 2007). Rendemen yang dihasilkan dalam penelitian ini hampir sama dengan penelitian yang telah dilakukan Huppertz et al. (2004) yaitu 10-25\%, sementara keju segar Minas hasil penelitian Buriti et al. (2005) menghasilkan rendemen sebesar $4.3-9.6 \%$.

\section{Kualitas kimia keju lunak}

Salah satu karakteristik penting dalam penilaian mutu susu pada pembuatan keju adalah $\mathrm{pH}$ karena $\mathrm{pH}$ medium sangat penting bagi stabilitas bakteri probiotik selama penyimpanan (Kailasapathy et al. 2008). Nilai pH yang tinggi merupakan kondisi yang kurang menguntungkan bagi proses penggumpalan keju yang membutuhkan $\mathrm{pH}$ optimum yaitu asam (McSweeney, 2007). Nilai pH keju lunak dengan penambahan 
kultur BAL secara tunggal atau campuran dapat dilihat pada Tabel 3, sedangkan nilai $\mathrm{pH}$ selama penyimpanan dapat dilihat pada Tabel 4.

Tabel 3. Nilai pH keju lunak yang dihasilkan dari penambahan kultur bakteri asam laktat (BAL) secara tunggal atau campuran

\begin{tabular}{cc}
\hline Kultur BAL & Nilai pH Rataan \pm SD \\
\hline BL & $5.79 \pm 0.47^{\mathrm{a}}$ \\
LA & $5.15 \pm 0.65^{\mathrm{b}}$ \\
LL & $5.48 \pm 0.87^{\mathrm{ab}}$ \\
BL-LA & $5.11 \pm 0.72^{\mathrm{b}}$ \\
BL-LL & $5.53 \pm 0.82^{\mathrm{ab}}$ \\
LA-LL & $5.10 \pm 0.65^{\mathrm{b}}$ \\
BL-LA-LL & $5.14 \pm 0.75^{\mathrm{b}}$ \\
\hline
\end{tabular}

$\mathrm{BL}=$ Bifidobacterium longum, $\mathrm{LA}=$ Lactobacillus acidophilus, $\mathrm{LL}=$ Lactococcus lactis; $a, b$ huruf superskrip yang berbeda pada kolom yang sama berbeda nyata $(p<0.05)$

Tabel 4. Nilai pH keju lunak selama penyimpanan yang dihasilkan dari penambahan kultur bakteri asam laktat secara tungga atau campuran

\begin{tabular}{cc}
\hline Penyimpanan (hari) & Nilai pH Rataan \pm SD \\
\hline H-0 & $6.09 \pm 0.17^{\mathrm{a}}$ \\
$\mathrm{H}-1$ & $5.30 \pm 0.52^{\mathrm{b}}$ \\
$\mathrm{H}-7$ & $5.05 \pm 0.73^{\mathrm{bc}}$ \\
$\mathrm{H}-14$ & $4.88 \pm 0.77^{\mathrm{c}}$ \\
\hline
\end{tabular}

$\mathrm{H}-0=$ hari ketika penambahan kultur starter, $\mathrm{H} 1-\mathrm{H} 14=$ hari penyimpanan ke-1, 7, dan 14

Berdasarkan analsis sidik ragam terdapat perbedaan $(p<0.05)$ pada kultur BAL, sehingga kultur BAL berpengaruh nyata terhadap nilai $\mathrm{pH}$ dan setelah uji Duncan kultur BAL dapat diketahui bahwa nilai pH keju lunak yang mengandung kultur $\mathrm{BL}$ tidak berbeda nyata dengan kultur LL dan BL-LL, sedangkan keju lunak yang mengandung kultur LA-LL berbeda tidak nyata dengan semua perlakuan, kecuali keju lunak yang mengandung kultur BL. Nilai pH susu merupakan faktor penting selama fase penggumpalan pada proses pembuatan keju. Nilai $\mathrm{pH}$ bervariasi karena adanya reaksi kultur starter, proses sebelum pematangan atau adanya penambahan asam. Nilai $\mathrm{pH}$ mempengaruhi aktivitas proteolitik karena terjadi pemecahan makropeptida kappa kasein oleh rennet (Ong et al. 2012). Selama fase pembuatan keju, laktosa dirubah menjadi asam laktat, sehingga meningkatkan $\mathrm{pH}$, namun ketika nutrisi tidak tersedia, maka mikroflora memetabolisme asam amino yang dilepaskan dari kasein (McSweeney dan Sousa, 2000).

Bifidobakteria tumbuh optimum pada $\mathrm{pH}$ 6.5-7.0 dan akan terhambat di bawah pH 5.0 atau di atas pH 8.0 (Bolyston, 2004). Bifidobacterium longum dibedakan dari spesies Bifidobakteria lain, karena dapat memanfaatkan arabinosa, xilosa, ribosa, laktosa, melesitol, trehalosa dan tidak dapat memanfaatkan glukonat, maltosa dan salisin (Hadadji dan Bensoltane, 2006). Bifidobacterium longum tumbuh baik pada media TPY yang mengadung laktosa dengan laju pertumbuhan 0.37 per jam. Nilai pH kultur menurun secara bertahap dari 6.7 ke 4.1 setelah 23 jam inkubasi pada $37^{\circ} \mathrm{C}$, namun pertumbuhan $B$. longum relatif tidak terpengaruh. Rataan nilai $\mathrm{pH}$ selama penyimpanan dapat dilihat pada Gambar 6.

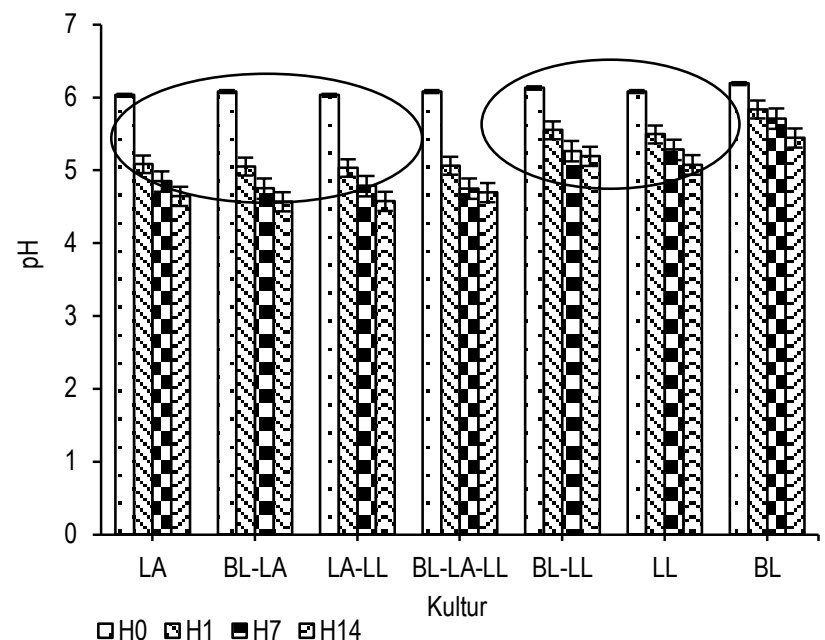

Gambar 6. Diagram batang rataan nilai pH selama penyimpanan keju lunak yang dihasilkan dari penambahan kultur bakteri asam laktat (BAL) secara tunggal atau campuran

Gambar 6. terlihat bahwa keju lunak dengan pe-nambahan kultur LA, baik tunggal atau campuran menunjukkan nilai $\mathrm{pH}$ yang lebih rendah (6.08 menjadi 4.64) dibandingkan kultur lainnya (6.19 menjadi 5.07), hal ini menunjukkan bahwa penambahan kultur $L$. acidophilus ternyata mampu menurunkan tingkat keasaman keju lunak, karena menurut Vedamuthu (2006) walaupun L. acidophilus tumbuh lambat di dalam susu, namun memproduksi asam laktat dalam jumlah tinggi, sehingga dapat berperan sebagai faktor pengasam. Produk keju yang mengandung $L$. acidophilus mempunyai kandungan asam laktat yang tetap selama penyimpanan, karena banyak laktosa yang hilang bersama whey dan hanya sedikit yang tersisa dalam keju (Ong et al. 2006). Selama penyimpanan, dapat terjadi perubahan struktural karena hilangnya kelembaban dan perubahan biokimia, serta perubahan keju secara umum (Madadlou et al. 2007).

Berdasarkan analsis sidik ragam terdapat perbedaan $(p<0.05)$ pada penyimpanan, sehingga penyimpanan berpengaruh nyata terhadap nilai $\mathrm{pH}$ dan setelah uji Duncan penyimpanan diketahui bahwa rata-rata $\mathrm{pH}$ tertinggi dihasilkan pada penyimpanan $\mathrm{H}-\mathrm{O}$ (6.09), sedangkan terendah pada penyimpanan $\mathrm{H}-14$ (4.88). Tidak terjadi interaksi antara kultur BAL dan lama penyimpanan, karena memiliki $p$-value $0.999>0$ $5 \%(p>0.05)$. Kadar $\mathrm{pH}$ pada awal penyimpanan lebih tinggi karena pada $\mathrm{H} 0$ merupakan saat penambahan kultur pada susu, dimana pH awal susu setelah pasteurisasi sebesar 6.4 turun menjadi 6.09 setelah penambahan kultur bakteri asam laktat. Penurunan terus terjadi selama masa penyimpanan, hal ini dimungkinkan karena proses metabolisme berlangsung secara ideal dan kondisi konstan, dimana tingkat produksi asam sebanding dengan jumlah bakteri, walaupun ketika pertumbuhan melambat atau bahkan berhenti karena terjadi akumulasi asam laktat, sistem enzim bakteri masih dapat terus melanjutkan perubahan dari laktosa menjadi asam. Kondisi pertumbuhan bakteri tidak persis sama seperti yang terjadi pada starter akibat perlakuan panas pada susu dan tekanan oksigen di 
dalamnya, sehingga enzim bakteri yang ditambahkan harus menyesuaikan terlebih dahulu (Walstra et al. 2006).

Hasil penelitian menunjukkan terdapat perbedaan yang nyata $(p<0.05)$ terhadap kandungan karbohidrat by difference dan lemak, namun kadar air, protein dan abu tidak menunjukkan perbedaan yang nyata pada semua kultur yang ditambahkan, baik secara tunggal atau campuran. Keju lunak yang mengandung kultur bakteri asam laktat BL-LL menghasilkan kadar lemak paling rendah, sehingga diharapkan keju ini dapat dijadikan sebagai alternatif pangan fungsional. Kombinasi BL-LA akan meningkatkan $45 \%$ produksi asam laktat, selain itu dapat memberikan dampak positif terhadap pengaruh bifidogenik dan mampu merangsang produksi asam laktat (Hadadji dan Bensoltane, 2006). Hasil analisis proksimat keju lunak probiotik yang dihasilkan dari penambahan kultur bakteri asam laktat secara tunggal atau campuran dapat dilihat pada Tabel 5.

Tabel 5. Hasil analisis proksimat keju lunak yang dihasilkan dari penambahan kultur bakteri asam laktat secara tunggal atau campuran

\begin{tabular}{lccccc}
\hline $\begin{array}{c}\text { Kultur } \\
\text { Starter }\end{array}$ & $\begin{array}{c}\text { Kadar } \\
\text { Air } \\
(\%)^{\text {th }}\end{array}$ & $\begin{array}{c}\text { Protein } \\
\text { kasar } \\
(\%)^{\text {th }}\end{array}$ & $\begin{array}{c}\text { Karbohidrat } \\
\text { by Difference } \\
(\%)\end{array}$ & $\begin{array}{c}\text { Lemak } \\
\text { Kasar } \\
(\%)\end{array}$ & $\begin{array}{c}\text { Abu } \\
(\%)^{\text {tn }}\end{array}$ \\
\hline BL & $57.7 \pm$ & $20.5 \pm$ & $13.1 \pm$ & $7.0 \pm$ & $1.7 \pm$ \\
& 0.5 & 2.7 & $0.5^{\mathrm{ab}}$ & $3.3^{\mathrm{ab}}$ & 0.3 \\
$\mathrm{LA}$ & $55.0 \pm$ & $20.9 \pm$ & $17.7 \pm$ & $5.1 \pm$ & $1.2 \pm$ \\
& 0.4 & 0.6 & $3.6^{\mathrm{a}}$ & $2.5^{\mathrm{ab}}$ & 0.1 \\
$\mathrm{LL}$ & $58.6 \pm$ & $20.7 \pm$ & $11.6 \pm$ & $7.4 \pm$ & $1.7 \pm$ \\
& 0.8 & 1.8 & $5.6^{\mathrm{ab}}$ & $6.0^{\mathrm{ab}}$ & 0.5 \\
BL-LA & $64.1 \pm$ & $21.6 \pm$ & $8.8 \pm$ & $4.0 \pm$ & $1.6 \pm$ \\
& 5.2 & 1.8 & $3.9^{\mathrm{ab}}$ & $2.7^{\mathrm{b}}$ & 0.4 \\
BL-LL & $63.4 \pm$ & $21.7 \pm$ & $6.7 \pm$ & $6.3 \pm$ & $2.0 \pm$ \\
& 10.7 & 1.5 & $3.44^{\mathrm{b}}$ & $4.2^{\mathrm{ab}}$ & 1.7 \\
LA-LL & $61.0 \pm$ & $20.2 \pm$ & $12.2 \pm$ & $5.2 \pm$ & $1.4 \pm$ \\
& 4.7 & 2.6 & $3.0^{\mathrm{ab}}$ & $4.0^{\mathrm{ab}}$ & 0.4 \\
BL-LA-LL & $63.6 \pm$ & $21.0 \pm$ & $4.6 \pm$ & $9.3 \pm$ & $1.4 \pm$ \\
& 5.8 & 1.2 & $3.1^{\mathrm{b}}$ & $6.8^{\mathrm{a}}$ & 0.9 \\
\hline
\end{tabular}

$\mathrm{BL}=$ Bifidobacterium longum, $\mathrm{LA}=$ Lactobacillus acidophilus, $\mathrm{LL}=$ Lactococcus lactis; a,b huruf superskrip yang berbeda pada kolom yang sama berbeda nyata $(p<0.05) .{ }^{\text {t }}=$ tidak berbeda nyata

Sampai saat ini standar tentang keju masih mengacu pada SNI 01-2980-1992, yaitu tentang keju cedar olahan dengan 45\% kadar air, 19.5\% kadar protein kasar, 25\% kadar lemak dan $5.5 \%$ kadar abu (BSN, 1992).

Berdasarkan kadar air yang dikandungnya (55-64.1\%), keju yang dihasilkan termasuk kelompok keju lunak, seperti diuraikan Heller et al. (2008) bahwa klasifikasi produk keju berdasarkan kadar air terbagi atas keju keras (20-24\%), keju semi keras atau semi lunak (45-55\%) dan keju lunak (>55\%), umumnya keju lunak dikonsumsi dalam keadaan segar dan mempunyai umur simpan yang terbatas. Kadar air yang tinggi dapat melemahkan jaringan kasein sehingga partikel keju mudah lepas (McSweeney, 2007). Protein susu merupakan zat penting dalam gizi dan fisiologi manusia. Protein dalam susu terbag atas kasein dan whey protein. Kasein merupakan kelompok dominan protein dalam susu, mengandung ester fosfat, prolin dan sedikit residu sistein, terdiri dari molekul as1, as2, $\beta$ dan $\mathrm{K}$, (Steijns, 2001). Keju lunak yang dihasilkan dari penambahan kultur bakteri probiotik mempunyai kandungan protein dan lemak masing-masing sebesar $13.50 \%$ dan $15.70 \%$ dan relatif sama setelah disimpan selama 28 hari yaitu sebesar $13.58 \%$ protein dan $15.94 \%$ lemak (Fritzen-Freire et al. 2010). Mutu keju yang dihasilkan dalam penelitian memiliki kandungan protein 20.2-21.7\%, hampir sama dengan keju cedar olahan 19.5\% (BSN, 1992) namun lebih besar dari hasil penelitian Buriti et al. (2007) yaitu sebesar $11.86 \%$ pada keju segar Minash yang mengandung $L$. acidophilus dan $13.44 \%$ pada keju probiotik yang menggunakan kultur Lactobacillus acidophilus (Kasimoglu et al. 2004), sehingga keju lunak yang dihasilkan pada penelitian ini dapat dijadikan sumber protein melebihi kandungan protein pada bahan dasarnya (3.8\%). Pembentukan asam amino dari protein juga penting dalam pematangan keju, dan merupakan senyawa prekursor dalam pembentukan flavor sebagai ciri khas pematangan keju (Walstra et al. 2006).

Kandungan karbohidrat by difference keju lunak yang mengandung bakteri tunggal LA berbeda nyata $(p<0.05)$ dengan keju lunak yang mengandung bakteri BL-LL dan BL-LA-LL, namun berbeda tidak nyata dengan yang ditambah bakteri $B L$, $\mathrm{LL}, \mathrm{BL}-\mathrm{LA}$ dan $\mathrm{LA}-\mathrm{LL}$, hal ini menunjukkan bahwa bakteri $\mathrm{LA}$ mampu bersinbiotik dengan bakteri BL dan LL untuk menghasilkan energi dalam proses metabolismenya. Metabolisme heksosa melalui jalur Emden-Meyerhoff mengarah ke produksi laktat dengan piruvat. Banyak jalur alternatif BAL untuk menghasilkan piruvat dan metabolit selain laktat, seperti metabolisme heksosa pada kondisi glukosa terbatas atau dengan adanya oksigen sebagai elektron akseptor (Axelson, 2004).

Lactococcus lactis mampu mengkonversi piruvat menjadi aasetolaktat ketika terdapat elektron akseptor seperti sitrat dan terjadi kelebihan piruvat relatif terhadap kebutuhan $\mathrm{NADH}$ melalui reaksi laktat dehidrogenase, dimana a-asetolaktat secara enzimatik diurai menjadi acetoin atau dikonversi secara non enzimatik terhadap senyawa rasa (Hugenholtz et al. 2002.) yaitu diasetil (Hansen dan Schieberle, 2005). Lactococcus lactis subsp. lactis dan Lactococcus lactis subsp. cremoris dalam fermentasi susu berperan sebagai pengasam, terutama dalam memproduksi asam laktat dan berkontribusi pada pengembangan tekstur dengan memproduksi eksopolisakarida atau senyawa aromatik sitrat, asam amino atau dalam metabolisme (Smit et al. 2005) sehingga membantu dalam menilai keamanan kultur yang digunakan (Kok et al. 2005).

Kadar lemak keju lunak yang mengandung bakteri BL-LA (4.0) berbeda lebih kecil dari keju lunak yang mengandung bakteri BL-LA-LL (9.3\%). Klasifikasi keju berdasarkan kadar lemaknya menurut standar umum keju Codex terdiri atas tinggi lemak $(>60 \%)$, lemak penuh (40-60\%), lemak sedang (25-45\%), lemak rendah (10-25\%). Keju yang dihasilkan tergolong ke dalam keju lunak dengan kadar lemak yang rendah, kondisi ini terjadi karena keju lunak yang digunakan menggunakan bakteri asam laktat baik secara tunggal atau campuran. Populasi mikroba dalam curd berhubungan dengan kandungan lemak keju. Pembuatan keju rendah lemak tergantung dengan teknik pengolahan, kultur starter dan penggunaan zat tambahan seperti penstabil dan lemak pengganti. Pemberian kultur starter dalam pembuatan keju berkontribusi terhadap proteolisis yang menyebabkan perubahan karakteristik tekstur dan rasa yang khas karena terjadi perubahan lingkungan dalam proses metabolismenya, sehingga penambahan kultur starter tetap harus dibatasi agar aktivitas proteolitik dapat terkendali (Mistry, 2001). 
Produk yang dihasilkan dari kultur campuran mempunyai spektrum luas dan komposisi yang kompleks dengan kandungan antibiotik, namun belum ditemukan metode yang dapat menghitung populasi $L$. acidophilus, L. casei dan Bifidobacterium secara bersamaan (Talwalkar dan Kailasapathy, 2004a) sehingga harus dipilih metode selektif, dikhususkan pada jenis makanan, spesies dan strain (Sartory, 2005).

\section{Kualitas mikrobiologi keju lunak}

Pembuatan keju yang menggunakan kultur bakteri, hal yang harus diperhatikan adalah kelangsungan hidup bakteri tersebut dalam matriks keju selama proses produksi dalam jumlah yang cukup dengan menghitung unit koloni (CFU) (Reid, 2008), namun Ong et al. (2006) mengemukakan bahwa penambahan mikroorganisme probiotik tidak berpengaruh langsung terhadap komposisi keju cedar yang disimpan pada suhu $4^{\circ} \mathrm{C}$ (garam, lemak, protein dan $\mathrm{pH}$ ). Produk susu fermentasi merupakan cara yang umum dilakukan dalam memanfaatkan bakteri probiotik komersil dalam makanan, seperti $L$. acidophilus $L$. casei dan Bifidobacterium (Temmerman et al. 2003). Kultur $L$. acidophilus dapat juga digunakan dalam pembuatan keju probiotik Turkish dengan populasi $10^{7} \mathrm{CFU} / \mathrm{g}$ (Kasimoğlu et al. 2004). Jumlah minimum bakteri probiotik yang dibutuhkan untuk memperoleh efek kesehatan belum ditetapkan (Roy, 2005). Namun, menurut Chen dan Walker (2005), cara terbaik untuk mendapatkan manfaat probiotik adalah dengan mengonsumsinya secara rutin, sehingga mampu mempertahankan atau meningkatkan keseimbangan mikroba usus. Populasi Bifidobacterium Bb-12 dalam keju Cheddar yang disimpan selama 32 minggu mengandung sebesar 8 log CFU/g sel probiotik (Phillips et al. 2006) namun demikinan B. longum 15708 sangat sensitif terhadap kondisi asam (Kheadr et al. 2007). Jumlah BAL yang ditambahkan baik secara tunggal atau campuran dan selama penyimpanan dapat dilihat pada Tabel 6 dan Tabel 7.

Penggunaan media selektif memungkinkan pertumbuhan bakteri yang diharapkan dan menghambat bakteri lainnya (Darukaradhya et al. 2006). Jumlah mikroba merupakan indikator aktivitas bakteri. Jumlah BAL keju lunak yang menggunakan bakteri campuran BL-LA-LL (9.38 CFU/g) berbeda nyata $(p<0.05)$ dibanding jumlah $\mathrm{BAL}$ yang menggunakan bakteri BL dan BL-LA (9.09 CFU/g). Tingginya jumlah BAL pada keju lunak yang ditambahkan secara tunggal atau campuran memberi indikasi bahwa pemberian bakteri campuran tidak menyebabkan penghambatan terhadap bakteri lainnya dan mampu bersinbiotik, sehingga mampu mencapai jumlah maksimal 9.38 CFU/g. Pertumbuhan $B$. bifidum dan $B$. longum meningkatkan populasi 1-2 $\log _{10}$, sementara populasi $B$. infantis menurun 1 $\log _{10}$ selama 14 hari periode pematangan (Boylston, 2004).

Agar dapat dikategorikan sebagai produk makanan sehat dan tetap layak selama penyimpanan, hal pertama yang harus dikontrol adalah jumlah mikroorganisme probiotik dalam produk keju yang dihasilkan karena bakteri probiotik menekankan pada perlunya bakteri yang hidup ketika dikonsumsi (Farnworth dan Champagne, 2010). Salah satu metode yang dikenal untuk meningkatkan keamanan mikrobiologi dalam produk makanan adalah dengan cara pemasakan, aktivitas air, penyesuaian $\mathrm{pH}$ atau menggunakan pengawet, namun metode ini umumnya dapat mengurangi sifat organoleptik produk (Zheng dan Kennett, 2008) dan menurunkan populasi B. Iongum 15708 dengan cepat sehingga penggunaannya membutuhkan pendekatan lain yang dapat mempertahankan daya hidupnya selama produksi dan penyimpanan (Ding dan Shah, 2007; Talwalkar dan Kailasapathy, 2004b).

Tabel 6. Jumlah bakteri asam laktat (BAL) keju lunak yang dihasilkan dari penambahan kultur BAL secara tunggal atau campuran

\begin{tabular}{lc}
\hline \multicolumn{1}{c}{ Kultur Starter } & Populasi BAL (Log ${ }_{10}$ CFU/g) \\
\hline BL & $9.09 \pm 0.29^{\mathrm{b}}$ \\
LA & $9.28 \pm 0.23^{\mathrm{ab}}$ \\
LL & $9.33 \pm 0.11^{\mathrm{ab}}$ \\
BL-LA & $9.09 \pm 0.21^{\mathrm{b}}$ \\
BL-LL & $9.17 \pm 0.17^{\mathrm{ab}}$ \\
LA-LL & $9.32 \pm 0.40^{\mathrm{ab}}$ \\
BL-LA-LL & $9.38 \pm 0.42^{\mathrm{a}}$ \\
\hline
\end{tabular}

$\overline{\mathrm{BL}}=$ Bifidobacterium longum, $\mathrm{LA}=$ Lactobacillus acidophilus, $\mathrm{LL}=$ Lactococcus lactis; a,b huruf superskrip yang berbeda pada kolom yang sama berbeda nyata $(p<0.05)$

Tabel 7. Jumlah bakteri asam laktat (BAL) selama penyimpanan

\begin{tabular}{lc}
\hline \multicolumn{1}{c}{ Kultur Starter } & Populasi BAL (Log 10 CFU/g) \\
\hline $\mathrm{H}-1$ & $9.34 \pm 0.32^{\mathrm{a}}$ \\
$\mathrm{H}-7$ & $9.15 \pm 0.27^{\mathrm{b}}$ \\
$\mathrm{H}-14$ & $9.19 \pm 0.23^{\mathrm{b}}$ \\
\hline
\end{tabular}

$\mathrm{BL}=$ Bifidobacterium longum, $\mathrm{LA}=$ Lactobacillus acidophilus, $\mathrm{LL}=$ Lactococcus lactis; a,b huruf superskrip yang berbeda pada kolom yang sama berbeda nyata $(p<0.05)$

Jumlah kultur starter probiotik tergantung pada matriks keju dan target yang akan dicapai, seperti mengetahui latar belakang taksonomi dan fungsi bakteri yang digunakan, sehingga penggunaan media yang selektif sangat disarankan (Karimi et al. 2012). Keju segar memiliki umur simpan yang sangat terbatas dan mudah terkena mikroba patogen psikotropika sehingga perlu diupayakan untuk meningkatkan keamanan mikrobiologis produk. Populasi mikroba yang terdapat dalam dadih keju dipengaruhi oleh retensi pada saat renneting, kehilangan selama proses pengeluaran whey, proses cheddaring atau penggaraman dan turunnya viabilitas (daya tumbuh) pada saat proses selama 3-5 jam (Fortin et al. 2011). Berdasarkan uji Duncan terhadap penyimpanan, dapat diketahui bahwa terdapat perbedaan yang nyata $(p<0.05)$ terhadap jumlah $B A L$ yang disimpan selama 1 hari $(9.34 \mathrm{CFU} / \mathrm{g}$ ) dibanding jumlah BAL setelah disimpan selama 7 dan 14 hari. Perubahan yang terjadi pada jumlah BAL disebabkan adanya kompetisi nutrisi pada proses penyimpanan, dimana bakteri yang satu menghambat pertumbuhan bakteri lainnya. Walau lama penyimpanan menyebabkan perbedaan terhadap jumlah BAL, namun jumlah BAL dalam keju lunak masih menunjukkan populasi yang tinggi (9.15-9.38 CFU/g), sehingga dapat dikategorikan sebagai probiotik dan menunjukkan BAL yang ditambahkan mampu beradaptasi terhadap matrik keju sehingga mampu bertahan selama 14 hari penyimpanan pada suhu $5^{\circ} \mathrm{C}$. Komponenkomponen yang membentuk matrik keju berperan melindungi bakteri probiotik selama melewati saluran pencernaan dan selama penyimpanan, karena keju mempunyai konsistensi 
padat, kadar lemak dan $\mathrm{pH}$ yang lebih tinggi dibanding produk fermentasi lainnya (Boylston, 2004).

\section{KESIMPULAN}

Penambahan kultur bakteri asam laktat menurunkan $\mathrm{pH}$ selama 14 hari penyimpanan dengan karakteristik keju lunak. Penambahan bakteri LA secara tunggal menghasilkan karbohidrat lebih tinggi dibandingkan penambahan LA secara campuran dengan kadar lemak yang rendah. Kombinasi ketiga kultur starter yang ditambahkan secara tunggal atau campuran tidak menyebabkan penghambatan pada kultur yang lain, sehingga mencapai jumlah di atas $9.0 \log _{10} \mathrm{CFU} / \mathrm{g}$ dan tetap bertahan selama penyimpanan 14 hari sehingga berpotensi sebagai kandidat makanan probiotik.

\section{UCAPAN TERIMA KASIH}

Terima kasih disampaikan kepada Kementerian Riset dan Teknologi RI, Jakarta dan Pusat Penelitian Bioteknologi LIPI, Cibinong.

\section{DAFTAR PUSTAKA}

Axelson L. 2004. Lactic Acid Bacteria: Classification and Physiology. In: Salminen S, von Wright AT, Ouwehand A. 2004. Lactic Acid Bacteria: Microbiological and Functional Aspects. $3^{\text {rd }}$ ed. NY: Marcell Dekker Inc. Hal 629.

Boylston TD, Vinderola CG, Ghoddusi HB, Reinheimer JA. 2004. Incorporation of bifidobacteria into cheeses: challenges and rewards. Int Dairy J 14: 375-387. DOI: 10.1016/j.idairyj.2003.08.008.

[BSN] Badan Standardisasi Nasional. 2011. SNI No. 3141.1:2011. Susu Segar. Badan Standardisasi Nasional Jakarta.

[BSN] Badan Standardisasi Nasional. 1992. SNI No. 01-29801992. Keju Cedar olahan. Badan Standardisasi Nasional Jakarta.

Buriti FCA, da Rocha JS, Saad SMI. 2005. Incorporation of Lactobacillus acidophilus in Minas fresh cheese and its implications for textural and sensorial properties during storage. Int Dairy J 15: 1279-1288. DOI: 10.1016/j.idairyj. 2004.12.011.

Buriti FCA, Okazaki TY, Alegro JH, Alergo, Saad SM. 2007. Effect of a probiotic mixed culture on texture profile and sensory performance of Minas fresh cheese in comparison with the traditional products. Archv Lat Am Nutr 57: 179185.

Casalta E, Montel MC. 2008. Safety assessment of dairy microorganisms: the Lactococcus genus. Int J Food Microbiol 126: 271-273. DOI: 10.1016/j.ijfoodmicro. 2007.08.013.
Chen CC, Walker WA. 2005. Probiotics and prebiotics: role in clinical disease states. Adv Padiatr 52: 77-113. DOI: 10. 1016/j.yapd.2005.03.001.

Darukaradhya J, Phillips M, Kailasapathy K. 2006. Selective enumeration of Lactobacillus acidophilus, Bifidobacterium spp, starter lactic acid bacteria and non starter lactic acid bacteria from cheddar cheese. Int Dairy J 16: 439-445. DOI: 10.1016/j.idairyj.2005.06.009.

Ding WK, Shah NP. 2007. Acid, bile and heat tolerance of free and microencapsulated probiotic bacteria. J Food Sci 72: M446-M450. DOI: 10.1111/j.1750-3841.2007.00565.x.

Everett DW, Auty MAE. 2008. Cheese structure and current methods of analysis. Int Dairy J: 759-773. DOI: 10.1016/j. idairyj.2008.03.012.

Farke NY. 2004. Cheese technology. Int Dairy J Tech 57: 91-98.

Farnworth ER, Champagne C. 2010. Bioactive Foods in Promoting Health. Probiotics and Prebiotics. Elsevier Inc.

Fritzen-Freire CB, Müller CMO, Laurindo JB, Prudencio. 2010. The influence of Bifidobacterium Bb-12 and lactic acid incorporation on the properties of Minas Frescal cheese. $J$ Food Eng 96: 621-627. DOI: 10.1016/j.jfoodeng.2009.09. 010.

Fortin MH, Champagne CP, St-Gelais D, Britten M. 2011. Effect of time of inoculation, starter addition, oxygen level and salting on the viability of probiotic cultures during cheddar cheese production. Int Dairy J 21: 75-82. DOI: 10.1016/j. idairyj.2010.09.007

Hansen A, Schieberle P. 2005. Generation of aroma compounds during sourdough fermentation: applied and fundamental aspects. Trends Food Sci Technol 16: 85-94. DOI: 10.1016/j.tifs.2004.03.007.

Hadadji M, Bensoltane A. 2006. Growth and lactic acid production by Bifidobacterium longum and Lactobalillus acidophilus in goat's milk. Afr J Biotechnol 5: 505-509.

Heller KJ, Bockelmann W, Schrezenmeir J, de Verse M. 2008. Cheese and Its Potential as a Probiotic Food. In: Farnworth ER. (Ed). Handbook of Fermented Functional Foods. $2^{\text {nd }}$ ed. US: CRC Pr.

Homayouni A, Azizi A, Ehsani MR, Yarmand MS, Razavi SH. 2008. Effect of microencapsulation and resistant starch on the probiotic survival and sensory properties of synbiotic ice cream. Food Chem 111: 50-55. DOI: 10.1016/j.foodchem. 2008.03.036.

Huppertz T, Patrick FF, Kelly AL. 2004. Effects of high pressure treatment on the yield of cheese curd from bovine milk. Innov Food Sci Emer 5: 1-8. DOI: 10.1016/j.ifset. 2003. 09.001.

Jamilatun M. 2009. Optimalisasi Fermentasi Rhizopus oryzae dalam Pembentukan curd dan Analisis Kualitas Keju Mentah yang Terbentuk. [Tesis]. Program Pascasarjana. Universitas Sebelas Maret. Surakarta.

Jandu N, Zeng ZJ, Johnson-Henry KC, Sherman PM. 2009. Probiotics prevent enterohaemorrhagic Escherichia coli 0157:H7-mediated inhibition of interferon-gamma-induced 
tyrosine phosphorylation of STAT-1. Microbiol 155: 531-540. DOI: 10.1099/mic.0.021931-0.

Kailasapathy K, Harmstorf I, Phillips M. 2008. Survival of Lactobacillus acidophilus and Bifidobacterium animalis spp. lactis in strirred fruit yogurts. LWT-Food Sci Technol 41: 1317-1322. DOI: 10.1016/.IIwt.2007.08.009.

Karimi R, Mortazavian AM, Da Cruz AG. 2011. Viability of probiotic microorganisms in cheese during production and storage [Review]. Dairy Sci Technol 91: 283-308. DOI: 10.1007/s13594-011-0005-x.

Karimi R, Mortazavian AM, Amiri-Rigi A. 2012. Selective enumeration of probiotic microorganisms in cheese. Food Microbiol 29: 1-9. DOI: 10.1016/j.fm.2011.08.008.

Kasimoğlu A, Göncüoğlu M, Akgü A. 2004. Probiotic white cheese with Lactobacillus acidophilus. Int Dairy J 14: 10671073. DOI: 10.1016/j.idairyj.2004.04.006.

Kheadr E, Dabour N, Le Lay C, Lacroix C, Fliss J. 2007. Antibiotic susceptibility profile of bifidobacteria as affected by oxgall, acid and hydrogen peroxide stress. Antimicrobiol Agent Chemo 51: 169-174. DOI: 10.1128/AAC.00261-06.

Kok J, Buist G, Zomer AL, van Hijum SAFT, Kuipers OP. 2005. Comparative and functional genomics of lactococci [Review]. FEMS Microbiol Rev 29: 411-433.

Kusmiati, Malik A. 2002. Aktivitas bakteriosin dari bakteri Leuconostoc mesenteroides pada berbagai media. Makara Kesehatan 6: 1-7.

Madureira A, Pereira Cl, Truszkwoska K, Gomes AM, Pintado ME, Malcata FX. 2005. Survival of probiotic bacteria in a whey cheese vector submitted to environmental conditions prevailing in the gastrointestinal tract. Int Dairy J 15: 921927. DOI: 10.1016/j.idairyj.2004.08.025.

Maheswari RRA, Wiryawan IKG, Maduningsih GL. 2008. Stability of two probiotics bacteria of goat milk yoghurt in rat digestive tract. Microbiol 2: 124-130.

McSweeney PLH. 2007. Cheese Problems Solved. England: CRS Pr.

McSweeney PLH, Sousa MJ. 2000. Biochemical pathways for the production of flavour compounds in cheeses during ripening [Review]. Le Lait Dairy Sci Technol 80: 293-324. DOI: 10.1051/lait:2000127.

Mistry VV. 2001. Low fat cheese technology. Int Dairy J 11: 413422. DOI: 10.1016/S0958-6946(01)00077-2.

Odamaki T, Yonezawa S, Sugahara H, Xiao JZ, Yaeshima T, Iwatsuki K. 2011. A one step genotypic identification of Lactococcus lactis subspecies at the species/strain levels. Syst Appl Microbiol 34: 429-434. DOI: 10.1016/j.syapm. 2011.01.011.

Ong L, Henrikson A, Shah NP. 2006. Development of probiotic cheddar cheese containing $L b$. acidophilus, $L b$. paracasei, $L b$. casei and Bifidobacterium spp. and the influence of these bacteria on proteolytic patterns and production of organic acid. Int Dairy J 16: 446-456. DOI: 10.1016/j.idairyj. 2005.05.008.

Ong L, Dagastine RR, Kentish SE, Gras SL. 2012. The effect of $\mathrm{pH}$ at renneting on the microstructure, composition and texture of cheddar cheese. Food Res Int 48: 119-130. DOI: 10.1016/j.foodres.2012.02.020.

Phillips M, Kailasapathy K, Tran L. 2006. Viability of commercial probiotic cultures (L. acidophilus, Bifidobacterium sp., $L$. casei, L. paracasei and L. rhamnosus) in cheddar cheese. Int J Food Microbiol 108: 276-280. DOI: 10.1016/j. ijfoodmicro.2005.12.009.

Rautava S, Salminen S, Isolauri E. 2009. Specific probiotics in reducing the risk of acute infections in infancy-a randomised, double-blind, placebo-controlled study. British J Nutr 101: 1722-1726. DOl: 10.1017/S0007114508116282.

Reid G. 2008. Probiotics and prebiotics-progress and challenges. Int Dairy J 18: 969-975. DOI: 10.1016/j.idairyj. 2007.11.025.

Riahi MH, Trelea IC, Lecrercq MN, Picque D, Corrieu G. 2007. Model for changes in weight and dry matter during the ripening of a smear soft cheese under controlled temperature and relative humidity. Int Dairy J 17: 946-953. DOI: 10.1016/j.idairyj.2006.11.002.

Roy D. 2005. Technological aspects related to the use of bifidobacteria in dairy products. Le Lait Dairy Sci Technol 85: 39-56. DOI: 10.1051/lait:2004026.

Sanders ME. 2003. Probiotics: considerations for human health. [Reviews]. Nutr Rev 61: 91-99.

Sartory DP. 2005. Validation, verification and comparison: adopting new methods in water microbiology. SA Water Res Commi 31: 393-396.

Shah NP. 2007. Functional cultures and health benefits. Int Dairy J 17: 1262-1277. DOI: 10.1016/j.idairyj.2007.01.014.

Siddique F, Anjum FM, Huma N, Jamil A. 2010. Effect of different UHT processing temperatures on ash and lactose content of milk during storage at different temperatures. Int J Agr Biol 12: 439-442.

Steijns JM. 2001. Milk ingredients as nutraceuticals. Int J Dairy Technol 54: 81-88. DOI: 10.1046/j.1364-727x.2001.00019. $x$.

Talwalkar A, Kailasapathy K. 2004a. Comparison of selective and differential media for the accurate enumeration of strains of Lactobacillus acidophilus, Bifidobacterium spp. and Lactobacillus casei complex from commercial yoghurts. Int Dairy J 14: 143-149. 10.1016/S0958-6946(03)00172-9.

Talwalkar A, Kailasapathy K. 2004b. A review of oxygen toxicity on probiotic yoghurts: influence on the survival of probiotic bacteria and protective techniques. Comp Rev Food Sci Food S 3: 117-124. DOI: 10.1111/j.1541-4337.2004. tb00061.x.

Tamime AY, Robinson RK. 2000. Yoghurt: Science and Technology. $2^{\text {nd }}$ Edition. Boston: CRC Pr. 
Temmerman R, Scheirlinck I, Huys G, Swings J. 2003. Culture independent analysis of probiotic products by denaturing gradient gel electrophoresis. Appl Environ Microbiol 69: 220226. DOI: 10.1128/AEM.69.1.220-226.2003.

Vedamuthu ER. 2006. Starter Cultures for Yogurt and Fermented Milks. In: Chandan RC. (ed). Manufacturing Yogurt and Fermented Milks. US: Blackwell Pub Prof.

Wagar LE, Champagne CP, Buckley ND, Raymond Y, GreenJohnson JM. 2009. Immunomodulatory properties of fermented soy and dairy milks prepared with lactic acid bacteria. J Food Sci 74: M423-M430. DOI: 10.1111/j.17503841.2009.01308.x.

Walstra P, Wouters JTM, Geurts. 2006. Dairy Science and Technology. $2^{\text {nd }}$. NY:CRC.

Zheng Z, Kennett C. 2008. Methods of Making Fresh Cheese with Enhanced Microbiological Safety. US:Patent Appl Pub No. US2008/0152757 A1. 